\title{
Khul'(Redemption) in Islamic Law and Its Practice in Pakistani Courts, A Legal Critical Analysis
}

\author{
Muhammad Ifzal Mehmood \\ Department of Law, Faculty of Shariah and Law \\ International Islamic University, Islamabad, Pakistan \\ Email: ifzaalmehmood@gmail.com \\ Salman Farooq \\ Department of Law, Faculty of Shariah and Law \\ International Islamic University, Islamabad, Pakistan \\ Email: salman@uswat.edu.pk
}

Doi:10.5901/mjss.2014.v5n3p290

\begin{abstract}
Khul' is the proposal given to the husband by the wife for divorce. Divorce is the absolute right of the husband and no one other than the husband can use that right. Like divorce consent of the husband is necessary in khul'. In Pakistani courts this right is used by the judge which is against the opinion of majority of Islamic Jurists and also violates the absolute right of husband to pronounce talaq (divorce). Judicial Khul' is exercised in Pakistani courts, according to Article 2(ix) of dissolution of Muslims Marriages Act 1939. Khul' is considered talaq(divorce) and according to majority of Islamic Jurists (Jamhor) the husband has only two more options of divorce for constituting talaq mualaz. But in Pakistani courts it is not considered as talaq, which is contrary to the opinion of majority jurists (Jamhor) and there is need for the reformation. In this research detailed discussion is undergone to point out draw back in Article 2(ix) of dissolution Muslims marriages Act 1939 and recommendations are proposed for the amendments of this Act.
\end{abstract}

Keywords: Khul'(Redemption), Talaq (Divorce), Mubara'at (Mutual Freeing), Faskh-e-Nikah (Dissolution of Marriage), Qazi (Judge), Mahar (Compensation).

\section{Introduction}

The contract of marriage is intended to secure the interests of this world, including the protection of women and procreation as well as interests of the next world. The objective of the marriage is the creation of a perfect and happy life by the conduct of the spouses and such a life can only be created if there be mutual love and affection and if the limits imposed by God be observed (Nyazee, 2012). If for some reason, however, this does not seem possible, the objective of marriage is considered to have been defeated and it then becomes necessary to open the door of separation for the parties.

Separation in a marriage relationship can be achieved, inter alia, through talaq, Khul', Li'an, and Faskh. Islamic law recognizes unilateral and extra-judicial divorce at the initiative of the husband in the form of talaq. It also recognizes extra judicial divorce by mutual consent of the spouses in the form of mubara'at and another form of separation known as khul'(Carroll, 1996). In situations where a woman can no longer remain in the bond of marriage with her husband, the ideal solution would be for the wife to obtain a divorce from the husband. If the husband, determine that the marriage is unsuccessful and there is no hope for reconciliation, he should pronounce one divorce according to the prescribed method in Shari'ah. However, in the case where the husband refuses to utter a divorce, wife may persuade her husband to enter into an agreement of $\mathrm{khul}^{\prime}$

Like other agreements and transactions, an agreement for khul' will also come into effect by offer and acceptance (Kasani, $1328 \mathrm{~h}$ ). Allah almighty ordains: "but if you intend to take one wife in place of another, even if you had given the latter a whole treasure for dower, take not the least bit of it back. Would you take it by slander and a manifest wrong? And how could you take it when you have gone into each other, and they have taken from you a solemn covenant?"(AlQur'an).

In this Article we will analyze the concept of khul' according to our all school of thoughts and the procedure of 
courts followed. Another main issue which will be discussed as whether qazilcourt have authority to announce khul' if the husband did not agree to give divorce? Now two issues will arouse from this as if the woman would be permitted to get judicial khul' on the ground of disliking then the society and stability in homes will not be administered. On the other hand if she is not permitted then how they will live in a comfortable life. All these aspects will be covered in this research and there will be analyses of these aspects of our Jurists.

\section{Literature Review}

Khul' is the right of woman, which is constituted with the consent of the husband but in Pakistan courts it is granted by the court without the consent of husband. There are different books and articles written on this issue. In Pakistani courts there are too long debate conducted by the Jurists and Judges on this issue.

Lucy Carroll (1996) elaborate that Islamic law recognizes unilateral, extra-judicial divorce at the initiative of the husband in the form of talaq(divorce). It also recognizes extra judicial divorce by mutual consent of the spouses in the form of mubara'at and another form of judicial separation is known as khul'. He further commented that There are many questions arose here while giving the decision by the courts i.e. whether a divorce on the basis of Khul" can be decreed by the court in the face of the husband's opposition and whether Muslim Law recognized incompatibility of temperament as a ground for divorce? According to him the Act of 1939 was not a totally satisfactory answer to the problem of the Muslim women trapped in an unhappy and oppressive matrimonial situation. Women who sought divorce under the statute faced three major difficulties.

Imran Ahsan Khan (2012) gives the literal meaning of khul' is removing or taking off, like taking off a glove or shoes. Ibn Human (1999) define Khul" as "To remove the union of marriage in exchange for a financial settlement with the word of Khul ". Keith Hodkinson(1984) utters that talaq is the unilateral repudiation of a wife by her husband, while Faskh-e-Nikah is the dissolution of marriage by judicial degree. Al-Kasani(1328 h) proclaim that similar to other agreements and transactions, an agreement on khul' will also come into effect by offer and acceptance.

Abul Aala Maudodi(1981) elaborates that if the agreement is done by mutual consent then the compensation decided will be considered. But if the case is referred to court, then the court will investigate the reason behind the matter. If the court came to the conclusion that there is no way out expect the dissolution then the court will decide the compensation and the husband will pronounce divorce. He declares that the word "if you fear" addressed to a judge, or the head of the State. According to him khul' is synonymous with one irrevocable divorce, that is, after it the husband does not retain the right to turn his wife during the waiting period. But if a woman enters into second marriage with him, she can do so, for this is not final divorce, which entails the condition of tahlil(dissolution).

Asif A.A.Fyzee (1999) differentiate khul' from mubara'at. In the case of khul' the wife begs to be released and the husband agrees for a certain consideration which is usually a part or the whole of maher(compensation). While in mubara'at apparently both are happy at the prospect of being rid of each other

Muhammad Taqi Usmani (2001) clarify that Khul' is like talaq and it will be lawful on the conditions if it is fulfilled like talaq (divorce). The conditions and requirement of khul' is like that of talaq(divorce). He further clarify the interpretation of Imam Shafi in his book as khul' is talaq(divorce) and in another place he views that khul' is faskh-eNikah. Imam Shafi in his last saying declares that khul' is talaq(divorce). Habib urahman (2001) is of the opinion that khul' is talaq. Umer (Allah be pleased with him) and Usman (Allah be pleased with him) are also on the same opinion. If the spouses remarry after conducting khul' the husband will have two chance of divorce. After khul' if the husband pronounces two talaq (divorce) it will be considered Talaq-e-Mualaz.

K.N.Ahmad (1972) states that it is not essential for dissolving the marriage under khul' that the husband should be at fault. The case of Jamila fully establishes this view. The wife may not be able to live happily in such a case. Does Islam force her to live a miserable life and provide no relief for her? Can it be said that the unhappiness of the wife is no concern with Islamic law and it would rather let the wife adopt an undesirable code of conduct than to dissolve the marriage. The Quranic duty is to keep them with kindness requires that if mutual love cannot work, husband should release the wife from the bond of marriage.

\subsection{Hypotheses}

We will cover the following main issues in this Article:

- Whether the court can announce divorce on behalf of husband in the face of husband opposition?

- Whether the khul' is considered as faskh-e-nikah (dissolution of marriage) or talaq (divorce)? 
- Whether incompatibility of temperament constitutes ground for khul'?

- Whether the courts of Pakistan are following Islamic norms while conducting dissolution of Marriage?

\section{Research Method}

In this article we have followed qualitative method. We have collected different material regarding this issue. There are a lot of books written by Islamic jurists regarding the procedure of khul' and then we have discussed these books in context of its implication in Pakistani courts. First of all we have discussed the legality of khul' from the primary sources of Islamic Law Qur'an and Sunnah. After that conditions for the khul' is discussed and it is stated that whether the female can dissolve her marriage with the plea that her husband is ugly. In Pakistani courts there is procedure that dissolution of marriage is conducted without the consent of husband. We have consulted the books of Islamic scholars to conclude the matter. There are different articles written which is consulted about this issue.

\subsection{Scope of the Research}

Judicial khul' is an important issue faced to the courts of Pakistan. Pakistan following as a Hanafi school has restriction in judicial khul'. These restrictions are given in the Dissolution of Marriage Act 1939 which does not constitute all the grounds faced by the wife while getting her khul' (divorce). Human rights defenders have also raised an issue that the man have the authority to announce divorce while woman has no authority to get rid from the contract of Marriage. Another main issue which will be discussed in this research as whether Qazi/court have authority to announce khul' if the husband did not agree to give divorce? Abu-Hanifa is of the opinion that court have restricted to some extent as given in the dissolution of marriage act. As disliking of the wife towards her husband does not constitute dissolution of marriage. The court has authority to announce the dissolution of marriage if her husband did not want to do so (Maudodi, 2010).

Now two issues will arouse from this as if the woman would be permitted to get judicial khul' on the ground of disliking then the society and stability in homes will not be administered. On the other hand if she is not permitted then how they will live in a comfortable life. All these aspects will be covered in this research.

\section{Critical Analyses}

Family is the oldest and most resilient institution of society. From the beginning of human life, people have grouped themselves in the families to find emotional, physical and communal support. Marriage is the basic tool to form family. The contract of marriage is intended to secure the protection of women and family. A number of interests pertaining to this world and the next are associated with this contract. It is a means for the increase in the human population (Nyazee, 2012). Basic purpose of marriage is that both husband and wife live with love and affection, so that rights and duties prescribed by Allah should fulfilled. In Islamic Family Law this relation of Love between both is to be strengthened (Maudodi, 2010).

When marital relations are poisoned to a degree which makes a peaceful home life impossible and both fear that they may not be able to keep within the limits prescribed by Allah. In this case permission has been given to both male and female to release from the bond of marriage. This is the right given by Allah al-mighty to the spouses. If this right is exercised by the husband it is called talaq and in case it is claimed by the wife it is called khul'. Khul' is a kind of facility provided to the wife in securing divorce from her husband by returning a part or full amount of the mahar (Siddiqi, 1985). The lexical definition of khul' is "to remove the union of marriage in exchange for a financial settlement with the word of khul' "(Humam, 1999). Similar to other agreements and transactions, an agreement on khul' will also come into effect by offer and acceptance (Kasani, $1328 \mathrm{~h}$ ). The right of khul' is provided to the wife by Allah Al-mighty through Qur'an and different Ahadees (Saying of Prophet), in which she can demand the divorce from the husband against compensation which is dower according to Islamic jurists. If the desire to separate emanates from the wife it is called khul', if the divorce is affected by mutual aversion it is known as mubara'at and when commenced by judicial process is termed fasakh (judicial rescission)

Judicial khul' is exercised in Pakistani courts, which means that if a wife does not want to live with her husband she can file an application for khul' in court of law and the Judge will ask the husband to give her divorce against compensation. If the husband refuses then the court will give the divorce after six months on behalf of husband. Here some questions arises that (i) whether a divorce on the basis of khul' can be decreed by the court in the face of husband opposition (ii) whether the khul' is considered as faskh-e-nikah (dissolution of marriage) or talaq (divorce) (iii) whether 
incompatibility of temperament constitutes ground for divorce under Islamic law. We will discuss these issues in detail.

\subsection{Whether the court can announce divorce on behalf of husband in the face of husband opposition?}

Verse of Qur'an about khul' states that "And it is lawful for you that ye take from women aught of that which ye have given them; except (in the case)when both fear that they may not be able to keep the limits(imposed by)Allah. And if ye fear that they may not be able to keep the limits of Allah, in that case it is no sin for either of them if the women ransom herself" (Al- Quran).

Islamic Jurists have explained this verse differently. It is an agreement by the wife to pay compensation for terminating the contract of marriage. If the agreement is done by mutual consent then the compensation decided will be considered. But if the case is referred to court, then the court will investigate the reason behind the matter. If the court came to the conclusion that there is no way out expect the dissolution then the court will decide the compensation and the husband will pronounce divorce (Maudodi, 1981). J. A Rahman states that the words "if you fear" being addressed to the state, they can only mean that the state authorities is entitled to pass an order even though the husband does not agree. Islam does not force on the spouses a life devoid of harmony and happiness and if the parties cannot live together as they should, it permits a separation. If the dissolution is due to some default on the part of the husband, there is no need of any restitution. If the husband is not in any way at fault, there has to be restoration of property received by the wife and ordinarily it will be of the whole of the property but the Judge may take into consideration reciprocal benefits received by the husband and continuous living together also may be a benefit received (Serajuddin, 2011).

The verse is classified in three parts as 'if they fear that the limits prescribed by Allah will not be observed' 'it is lawful if you take the compensation which you have paid' 'there is no sin on you'. All these three parts of verse shows that there will be mutual understanding among the spouses for the conclusion of Khul'. And khul' is not announced without the consent of the male. If the case comes to the court then the Judge can give his suggestion for the khul' but the khul' will be announce on mutual understanding. At the time of Prophet (peace be on him) the People used to come to Hakim(ulol-ul-amar) for consultation of their problems and not only for decision of their matter. So in this verse it is stated that if someone consult you on any matter, you can give your opinion for khul' but cannot decide the khul' on the husband opposition (Usmani, 2001).

At the time of Prophet (Allah be pleased with him) famous leading case regarding khul' was that of Thabit Ibn Qais. The fact of the case is partly discussed in different Ahadees. Jamila bint Ubi bin salool hated the physical ugliness of her husband. She presented her case to the Messenger of Allah (peace and blessing be upon him) in the following words: "O Messenger of Allah! Nothing can ever unite his head with mine. When I raised my veil I saw him coming in the company of a few men and he was the darkest, shortest and ugliest of them.by God I do not dislike him because of any defect in his faith or morality .I just hate his ugly looks. By God! If I did not fear Allah, I would have spat on his face when he came near me". It is interpreted as "the messenger of Allah (peace and blessing of Allah be upon him) held that the complaint of the women that her husband was ugly and loathsome was adequate ground for granting khul'. When it is manifest that a man hates his wife or the wife hate her husband, Divorce and khul' are perfectly justified and valid measures, for the consequences of religion, morality and civilization of keeping a man and women forcibly yoked together are for worse than the consequences of Divorce and Khul'. The court has authority to pronounce talaq (divorce) on behalf of the husband, if husband refuse to give talaq (divorce). As the women right of khul' is parallel to man's right of divorce (Maudodi. 2010).

Another interpretation of this Hadith is given as 'prophet (peace be on him) said to the Thabit to get compensation and pronounce talaq(divorce). Thabit agreed and replied that he will enunciate. This shows that the Thabit agreed and the khul' can be conducted if the husband has no objection. All the jurists are concluded that this was not the order of the prophet but was suggestion for the Thabit and he validated his proposal (Usmani, 2001). If the qazi has authority to pronounce khul' then prophet will not consult Thabit on this matter but will issue order of khul'. In li'an the qazi has authority to separate the spouses without their consultation. If prophet have ordered of khul' without any consultation with Thabit, it will be considered that qazi has authority like that of li'an to order khul'(Jasas, 1347 h). S.A Rahman in case of Syeeda khnam interpret Hadith of Jamila as 'after the wife had spoken her mind, the husband put forward a claim for return of the garden which he had given her, it should be noticed that he did not protest against his wife behavior, and indeed, by asking for consideration, he must be deemed to have expressed willingness that the marriage bond should be broken in return for an advantage to be received by him. It only remained for the holy prophet to discover whether there was agreement on the part of the wife to the proposition offered by the husband, and the tradition makes it clear that the Holy Prophet did so and finding that there was a consensus between the parties, he gave a direction which stands as 
guidance for all other Muslim married couple for all time(Carroll, 1996). Thus from this Hadith it is shown that the khul' is matter of husband and wife and it is conducted on mutual understanding.

At the time of Umar (Allah be pleased with him) a case of women was brought. Woman wanted to take khul' from his husband as she was not pleased with him. Umar (Allah be pleased with him) advised the women to be patient and suggested that she should continue to live with her husband. The women refused, whereupon he shut her up in a room full of garbage. He released her from this prison after three days and asked; How was these days?" She replied, "By God, these were the only nights that I passed in peace. "On hearing this Umar (Allah be pleased with him) ordered her husband: "Give her khul', even of you obtain only her ear-rings" The order of Hazart Umer shows that the qazi has authority to announce khul" on behalf of husband. (Maudodi, 2010). Ibn Rushd writes that divorce is the right of man and the khul' is the right of female, if husband dislike his wife, he pronounce talaq(divorce) and if the wife dislike husband, she has the right of khul'(Usmani, 2001).

Islamic Jurists(fuqaha) have different views about the consent of husband in khul'. Imam Abu Hanifa says that consent of the husband is necessary in khul'. Sarakhsi elaborate khul' in Mabsut, 'it is permissible in khul' to consult the court and also permissible to terminate Nikah by mutual consent in home. In khul' it is necessary that the two parties will agree on separation. Requirement for khul' is that the husband will announce talaq (divorce) and wife will give compensation. Imam Malik is of the opinion that no arbitrator are required and nor (further) permission of spouses. The qazi (judge) have the authority to pronounce khul' on behalf of husband. According to Imam Malik when there is a dispute between the parties to a marriage, the judge should appoint two Hakims or arbitrators from the family of each, as is laid down in the Holy Qur'an, and if these Hakims fail to bring about a compromise, the Judge has the power to dissolve the marriage on such terms as he considers just and fair." Imam shafi is of the opinion about the consent of the husband is that khul' is like talaq (divorce) and no any other person (without husband) has right to pronounce talaq (Judge). The right of talaq cannot be used by other person other than his husband. The qazi cannot divorce his wife without his consent. Imam Shafi writes that khul' is talaq and no any other person can divorce her. He further mentions in his book that her father, Hakim and qazi cannot divorce her on behalf of the husband. Imam Ahmad Bin Hanbal also support the views of Imam Shafi that the khul' is a contract like talaq and there is no need of qazi to interfere. The absolute right of khul' is with the spouses and the qazi cannot dissociate the husband and wife without the consent of husband(Usmani, 2001). Alama Maufiquddin Ibn Qadama Hanbali(R.A) writes khul' is dissolution of contract with compensation; therefore there is no need of qazi. It is like talaq and there is no need of qazi in talaq. Muhammad (peace be on him) called the khul' as fidya, so it is cleared that there is compensation in khul' and the consensus of both the spouses is necessary. If a person want to do contract it is necessary that the other party is agreed upon the terms of the contract because he has to pay in response of that contract. Majority of jurists consider the permission of husband necessary for khul'. Imam Malik has another saying about khul' that the wife will be forced back to go with her husband if the husband does not want to be separated through khul'(Waleed, 1324).

\subsection{Whether the khul' is considered as faskh-e-nikah (dissolution of marriage) or talaq (divorce)?}

Talaq (divorce) is the unilateral repudiation of a wife by her husband, while Faskh-e-Nikah is the dissolution of marriage by judicial degree(Hodkinson, 1984). It refers to the power of qazi (judge) to annul a marriage on the application of the wife (Fyzee, 1997). It is a great topic of debate that khul' is talaq or faskh-e-nikah. Different Jurists have diverse views about khul', as it will be considered talaq or faskh-e-nikah. It is necessary to distinguish that if khul' comes under the definition of talaq(divorce) then the husband has two more options to utilize the power of talaq(divorce) while if it is considered as faskh-e-nikah then the husband can exercise his three options of talaq(divorce).

Imam Abu Hanifa is of the opinion that khul' is talaq. Umer (Allah be pleased with him) and Usman (Allah be pleased with him) are also on the same opinion. If the spouses remarry after conducting khul' the Husband will have two chance of divorce. After khul' if the husband pronounces two talaq it will be considered Talaq-e-Mualaz (Habib urahman, 2004). In Fitwa Alamgiriya it is stated that khul' is like talaq and it will be lawful on the conditions if it is fulfilled like talaq. The conditions and requirement of khul' is like that of talaq. Sarakhsi writes that khul' can be conducted by the qazi(judge) and also permissible without qazi (judge), basic requirement of Khul' is consent of both parties and compensation from the wife. The husband has the power to pronounce talaq. Khul' is considered as Talaq-e-Bayin and the wife will be bound to give compensation (Tanzil Urahman, 1984). It shows that khul' is like talaq (divorce). It cannot be conducted like Faskh-e-Nikah (Sarakhsi, $1324 \mathrm{H}$ )

Imam Shafi interprets that khul' is talaq and in another place he views that khul' is Faskh-e-Nikah. In his last saying he says that khul' is talaq (Usmani, 2001). Tavos and Dare Qutni are also on the opinion of Imam Shafi. Abdul 
Razaq says that if a person pronounces two talaq and after that dissolve his marriage by khul', that person can remarry her without halala. According to their opinion khul' is not like talaq and the male has the third option of talaq. Ibn Qayim writes that Usman and Ibn-e-Umar are on the finding that khul' is not in the category of talaq but it is faskh.

Imam Ahmad Bin Hanbal says that khul' is not considered as talaq but it comes in the category of Faskh-e-Nikah. So from concluding khul' the man's right of three talaq (divorce) will not be affected. (Tanzil Urahman, 1984). It is concluded that legally khul' falls in the category of talaq-e-bayin. In talq-e-rajghi the wife will be in the bond of nikah up to the iddat and in khul' there is complete separation of spouses, the husband compensation from the wife. The complete separation will be considered if there is Talaq-e-Bayin. The wife give compensation to rid from the complete matrimonial relation and it will be possible if she considers that there is no chance of return from the Husband side. The most appropriate example is that of Jamila as the Prophet said 'khal sabeelaha' to leave her path, it denotes talaq-e-bayin.

\subsection{Whether incompatibility of temperament constitutes ground for khul'?}

This is important issue that if wife dislike her husband, she can demand for judicial khul'? There are different opinions of jurists about incompatibility of temperament as valid ground for demanding and valid measures, for the consequences to religion, morality and civilization of keeping a man and women forcibly yoked together are far worse than the consequences of khul'. In case of Jamila, she hated her husband Thabit with intense hate. She came to prophet and said "effect separation between me and him as I hate him I saw him, from the side of my veil, coming amongst people. He was of the shortest stature, the ugliest in face and blackest in complexion. I do not prefer infidelity after accepting Islam". Thabit addressed the Prophet as "O prophet of Allah, order that she should return the garden I gave her. Jamila returned the garden to Thabit. It was contended on behalf of the women that if the prophet of Islam, functioning in a judicial capacity, had dissolved a marriage simply on the wife's plea that she hated her husband for no other reason than his physical unattractiveness, then a marriage could be dissolved by the qazi (judge) the instance of the wife (Carroll, 1996).

Abu Hanifa and other Islamic jurists says that the women cannot take khul' on the ground that her husband is ugly. If Islam allow this then every women will seek divorce through khul'. In case of Syeeda Khanam (1952), Lahore High court rejected the notion of Jamila's divorce that she had been granted by the Prophet in a judicial capacity. To be sure, Muhammad (peace be on him) had ordered Thabit to divorce his wife, and given the reverence with which the Prophet of Islam was held by his contemporaries, it would have be impossible for Thabit to have disobeyed such an order. Nevertheless, the important point was that even Prophet did not take it upon himself to dissolve the marriage; he had only ordered the husband to do so. The prophet's role in this affair was not that of Judge at all, the court concluded, but of law giver and the law which was established and exemplified by the episode was the law of khul'(Carroll. 1996).

\section{Summary}

The position of women at the time of advent of Islam was worst. Muhammad (peace be on him) introduced significant reforms to improve the status of women. He gave power of divorce to the husband and at the same time also give the right of khul" to the wife. Qur'an mention authority of khul" as "If is not lawful for you to take from them anything of what you have given them, unless both fear that they cannot keep within God's bounds. So if you fear that you cannot keep within God's bound, there is no crime in you both about what she ransoms herself with".

Khul' in its literal sense means "to draw off or dig up", and in law it signifies an agreement between the husband and wife, with a view to dissolve the contract of marriage in lieu of compensation paid by the wife to her husband. All jurists are of the opinion that khul' is permissible in Islam. Imam Abu Hanifa declares khul' on the condition when there is variance between the spouses at the extent that the limits prescribed by Allah are not followed. Khul' is permissible on that situation. Ibn Hazam says that if there is difference created among each other, they should go for reconciliation. If the matter is not been resolved then they should go to court to adjudicate the matter.

There is difference between dissolution of Marriage by mutual consent and dissolution by court. If the desire to separate emanates from the wife it is called khul'. But if the divorce is affected by mutual aversion it is known as mubara'at. At the time of Prophet (peace be on him) famous leading case regarding khul' was that of Thabit Ibn Qais. His wives came to Prophet (peace be on him) and complained about his Ugliness. And Prophet (peace be on him) declared khul' for them. A case of women was brought before Umar (Allah be pleased with him). Woman wanted to take khul' from his husband as she was not pleased with him. Umar (Allah be pleased with him) ordered her husband: "Give her khul", even of you obtain only her ear-rings. Another case was brought before Usman (Allah is pleased with him) who ordered the husband: 'take even the tiniest hair of her head and give her khul'. 
Judicial khul' is exercised in Pakistani courts, which means that if a wife does not want to live with her husband she can file an application for khul' in court of law and the Judge will ask the husband to give her divorce against compensation. There is time limit of six months for the husband to clarify his stance. If the husband refuses or fails to come in front of judge then the judge pronounce divorce after six months on the behalf of husband. here some questions arises that whether the Qazi/judge has the authority to enunciate divorce on behalf of husband?

There is different opinion of Jurists about the consent of the husband. Imam Abu Hanifa says 'wife cannot get her khul' without Consent of her Husband'. Imam Malik is of the view that qazi have the authority to pronounce khul' on behalf of husband. Imam shafi is of the opinion about the consent of the husband is that khul' is like talaq and no any other person(without husband) has right to pronounce talaq. Imam Ahmad Bin Hanbal also support the views of Shafi (Allah be pleased with him) that the khul' is a contract like talaq and there is no need of qazi to interfere. It shows that all Jurists are divided on the issue of consent of husband. In my view Imam Abu Hanifa gives detailed proof that khul' is like talaq and the right of talaq is only with the husband.

Another issue is that Khul' is whether Talaq or Faskh-e-Nikah. Imam Abu Hanifa is of the opinion that khul' is talaq. Imam Shafi interprets that Khul' is Faskh-e-Nikah. Imam Ahmad Bin Hanbal says that khul' is not considered as talaq but it comes in the category of Faskh-e-Nikah. So from concluding khul' the man's right of three talaq will not be affected. It is concluded that legally khul' falls in the category of talaq-e-bayin. In talq-e-rajghi the wife will be in the bond of nikah up to the iddat and in khul' there is complete separation of spouses, the husband compensation from the wife. The complete separation will be considered if there is Talaq-e-Bayin. The wife give compensation to rid from the complete matrimonial relation and it will be possible if she considers that there is no chance of return from the Husband side. The most appropriate example is that of Jamila as the Prophet said 'khal sabeelaha' to leave her path, it denotes talaq-e-bayin.

This discussion elaborate that khul' is talaq and the husband has only two more options of divorce. But in Pakistani courts it is not considered as talaq, which is contrary to the opinion of majority jurists (Jamhor) and there is need for the reformation of these laws.

\section{Concluding Remarks}

In forgoing discussion an attempt was made to highlight the already existing work in the injunction of Islam. Although this work will bring fruits only when steps are taken to raise awareness about the subject in society while utilizing the religious text for the purpose to complement other ongoing efforts. The task of endowing men and women with their due rights is the task of society as a whole; nevertheless, continuous efforts are needed at different level by all institutions. It is recommended that the contract of marriage is intended to secure the protection of women and family. A number of interests pertaining to this world and the next are associated with this contract. To fulfill this contract at every level man and women should understand the rights and duties bestowed upon them according to the teaching of Islam. Everyone should respect others rights so that the families are strengthen and more.

Basic purpose of law is to secure the rights of every individual of society. There are different legislations made to protect the rights of women. Khul' is the right of women like that of men right of talaq (divorce). In Pakistani law it is dealt in dissolution of Muslim Marriages Act 1939 under sub section 2(ix), which states that any other ground which is recognized as valid for the dissolution of marriage under Muslim Law. There is no specific section for khul'. Therefore a separate section should be added for khul' in Dissolution of Muslim Marriages Act 1939 to safe the women right of talaq.

Khul' is the proposal given to the husband by the wife for divorce. Divorce is the absolute right of the husband and no one other than the husband can use that right. Like divorce consent of the husband is necessary in khul'. In Pakistani courts this right is used by the judge which is against the opinion of majority of Islamic Jurists. There is need to review this law of dissolution of marriages. This law violates the absolute right of husband to pronounce talaq.

Laws are made to secure the interest of man and women and amended with the intension so that others rights are not affected. Khul' is considered talaq (divorce) and according to majority of Islamic Jurists (Jamhor) the husband has only two more options of divorce for constituting talaq mualaz. But in Pakistani courts it is not considered as talaq (divorce), which is contrary to the opinion of majority jurists (Jamhor) and there is need for the reformation of these laws.

\section{References}

Al-Qur'an (Religious Book of Islam revealed on Prophet Muhammad S.A.W)

A.A.Fyzee, A. (1999). Outlines Of Muhammadan Law . India: Oxford University press.

Ali, M. (1985). Divorce In Islam . England: woking Muslim mission and literary trust.

Al-Kasani. (1328 h). Bada'i al- Sana'i . Egypt: Matbaghatul Jamaliya. 
Al-Sarakhsi. (1324 h). Al-Mabsut. Egypt: Makhtaba-tu-Saghada.

C.M.Shafqat. (1955). The Muslim Marriage,dower and divorce . Lahore: The Law Book Company .

Carroll, L. (1996). Judicial Khul' in Pakistan, A Charter Granted to the Wife. Journal from the Indian Law Institute, 96.

Coulson, N. (1964). A History Of Islamic Law . Edinburgh: Edinburgh University Press.

Gerber, H. (1999). Islamic Law and Culture . Leiden: Brill.

Haider, N. (2000). Islamic Legal Reform: The case of Pakistan and Family Law. Yale Journal of Law and Feminism , 339.

Hamilton, C. (1957). The Hedaya. Lahore : Premiere Book House.

Hodkinson, K. (1984). Muslim Family Law. Australia: Crime Helm.

Humam, I. (1999). Fath al-Qadir . Lahore: Maktabt Urasheed.

Husain, I. (1989). Law and custom . Kashmir: Srinagar Law Publication.

K.N.Ahmad. (1972). The Muslim Law of Divorce . Islamabad: Islamic Research Institute.

Khan, I. A. (2012). Outlines of Muslim Personal Law. Lahore.: Federal Law House.

Khan, I. A. (2012). Outlines of Muslim Personal Law. Lahore: Federal Law House.

Khan, T. U. (1994). Women's Rights in Islam. Peshawar: National Research and Development Foundation.

Mahmood, T. (1982). The Muslim Law of India. Allahabad: The Law Book Company.

Maman, M. A. (1995). D F Mullah of Principles of Muhamadan Law. Lahore: PLD Publisher.

Mansoor, T. (1999). From Patriachy to Gender Equility. Family Law and its Impact on Women , 190.

Mansoori, T. (2009). Family Law In Islam. Islamabad: IRI Press.

Maudodi, A. A. (2010). Huqooq-uz-Zavjan. Lahore: Idara Tarjumanul Quran Private limited.

Menski, D. P. (1998). Muslim Family Law . London: Sweet \& Maxwell.

Munir, M. (2009). The Rights of Women and Role of Superior Judiciary in Pakistan. Pakistan Journal of Islamic Research, 271.

Nasir, j. (1990). Islamic Law of Personal Status. London: Graham \& trotman.

Patel, R. (2003). Women verses Men. Pakistan: Oxford Universty.

Qudama, I. (1367 h). Al Mughni . Egypt: Darul Manar.

Qureshi, M. A. (1992). Muslim Law of Marrige, Divorce and Maintanance. New Dehli: Deep and Deep.

Rushd, I. (1379 h). Bidayat-ul-mujtahid . Egypt: Mustafa al babi.

Sarakhsi, A. (1324 h). Al Mabsot. Egypt: Matbat ul saada.

Serajuddin, A. M. (2011). Secular Courts and Muslim Women of South Asia. Karachi: Oxford University.

Shafi, A. I. (1381 h). Kitab-ul-um Sharh Muta . Azhar: Maktaba tul Kulyaat.

Siddiqi, M. I. (1984). The Family Laws of Islam. Lahore.

Thanavi, M. A. (1996). Al-Heela al-Najiza li'l-Hilat Al-'Ajiza . Lahore: Al-Faisal Publisher.

Urahman, H. (2004). Ahkam-e-Talaq. Islamabad: IRI.

Urahman, T. (1984). Majmoa Qavaneen-e- Islam . Islamabad: Idara Tahqeeq Islami.

Usmani, M. T. (2001). Islam ma Khul' ki haqiqat . Karachi: Maman Publishers.

Waleed, A. (1324 h). Al Muntaqa . Egypt: Matbat ul saada.

Zakia-A-Siddiqui. (1993). Muslim Women . New Delhi: Md Publications. 